\title{
Analisis sisa makanan lunak rumah sakit pada penyelenggaraan makanan dengan sistem outsourcing di RSUD Gunung Jati Cirebon
}

\author{
M. Agus Ariefuddin', Tjahjono Kuntjoro², Yeni Prawiningdyah ${ }^{3}$
}

\begin{abstract}
Background: An indicator of success in maintaining quality of service in patient nutrition can be measured from leftovers. In average inpatients got soft food as much as $40.1 \%$ and about $20.5 \%$ of them have leftovers. One benefit of leftover data is that they can be used to evaluate provision of hospital foods. Leftovers indicate that there is a waste in food cost. Objective: To analyze leftovers of hospital soft food in the provision of food using outsourcing system at Gunung Jati Hospital of Cirebon Municipality.

Method: This was an observational study that used cross sectional design. Samples were as many as 93 patients. Data were analyzed quantitatively using chi square to identify in factors correlation the presence of leftovers and correlation in respondents' satisfaction with the quality of food with the presence of leftovers and to identify correlation of irrelevance with leftovers of hospital soft foods portion served with the presence of leftovers. Characteristics of respondents and cost of foods wasted were analyzed using univariate technique.

Result: The result of statistical analysis showed that there was significant correlation in sex, level of education, types of diseases and appetite on the presence of leftovers $(p<0.05)$ and there was no significant correlation based on age and class of hospitalization ( $p \geq 0.05$ ). There was no significant correlation in respondents' satisfaction with quality of foods on the presence of leftovers $(p \geq 0.05)$. There was significant correlation between irrelevances in the amount of soft food portion served on the presence of leftovers. Total cost foods wasted was Rp 12.559.12/day.

Conclusion: There was correlation in sex, level of education, types of diseases and appetite on the presence of leftovers. There was no significant correlation in respondents' satisfaction with quality of foods on the presence of leftovers $(p \geq 0.05)$. There was significant correlation between irrelevances in the amount of soft food portion served with leftovers. The cost of foods wasted based on class of hospitalization served greatly varied.
\end{abstract}

KEY WORDS standard of soft food portion served, leftovers, cost of foods wasted, outsourcing

\section{PENDAHULUAN}

Indikator keberhasilan pelaksanaan mutu pelayanan gizi di ruang rawat inap dapat dilihat melalui perkembangan keadaan gizi pasien dan banyaknya makanan yang tersisa. Salah satu upaya untuk mengevaluasi kualitas pelayanan gizi dapat dilakukan dengan mencatat banyaknya makanan yang tersisa (1). Data sisa makanan dapat dimanfaatkan untuk mengevaluasi standar makanan rumah sakit yang ada, penyelenggaraan, dan pelayanan makanan (2). Namun demikian, sampai sekarang standar makanan rumah sakit belum dilaksanakan dengan optimal dalam memenuhi kualitas pelayanan makanan (3).

Untuk mengatasi masalah tersebut, akhir-akhir ini beberapa rumah sakit di Indonesia, baik pemerintah maupun swasta menggunakan sistem outsourcing untuk menyediakan makanan bagi para pasien. Selain alasan di atas, beberapa faktor yang menyebabkan rumah sakit cenderung menggunakan sistem outsourcing antara lain: mengurangi kesibukan rumah sakit, keinginan rumah sakit memperoleh layanan boga yang lebih profesional dan sesuai dengan standar makanan yang diharuskan bagi pasien, keterbatasan jumlah pegawai, serta memberi kesempatan bersaing melalui bentuk layanan yang lebih maju (4).

Dana yang dialokasikan untuk makanan pada sistem outsourcing sangat bervariasi, tergantung dari standar makanan dan menu yang akan disajikan. Hal tersebut berdampak pada peningkatan biaya makan pasien, ditambah lagi orientasi penyelenggaraan sistem outsourcing yang umumnya berorientasi pada keuntungan (4).

Rumah Sakit Umum Daerah (RSUD) Gunung Jati Cirebon merupakan salah satu rumah sakit yang telah menggunakan sistem outsourcing untuk penyediaan makanan kepada pasien selama beberapa tahun ini. Walaupun penyelenggaraan makanan dengan sistem ini dilaksanakan oleh pihak lain, evaluasi yang berkaitan dengan sisa makanan yang diberikan kepada pasien tetap diperlukan guna peningkatan pelayanan kepada pasien. Hal ini berkaitan dengan Laporan Tahunan Instalasi Gizi RSUD Gunung Jati Cirebon (5) yang menunjukkan bahwa sisa makanan pasien mencapai 25-50\%, bahkan jumlah pasien yang meninggalkan sisa makanan di atas $50 \%$ sebanyak $12,1 \%$ dari keseluruhan pasien rawat inap. Sebagian besar dari sisa makanan tersebut merupakan makanan lunak, karena sebanyak $40,1 \%$ pasien yang dirawat inap di RSUD Gunung Jati Cirebon diketahui memperoleh

\footnotetext{
1 RSUD Gunung Jati Kota Cirebon, Jl. Kesambi No. 56 Kota Cirebon

2 Bapelkes Gombong, Jl. Wilis No. 1, Gombong, e-mail: kuntjahjono@yahoo.com

3 Instalasi Gizi RSUP Dr. Sardjito, Jl. Kesehatan Yogyakarta
} 
makanan lunak dan $59,9 \%$ sisanya merupakan makanan biasa, makanan saring, dan makanan lewat pipa.

Sisa makanan yang tidak dikonsumsi oleh pasien mengakibatkan kebutuhan gizi pasien tidak terpenuhi dan biaya terbuang secara sia-sia (6). Biaya yang terbuang dari sisa makanan tersebut menyebabkan anggaran makanan kurang efisien, sehingga berdampak terhadap besarnya biaya atau anggaran yang digunakan untuk pengadaan bahan makanan, khususnya biaya total bahan makanan (7). Sisa makanan yang melebihi $25 \%$ merupakan salah satu indikator kurang berhasilnya suatu penyelenggaraan makanan di rumah sakit (3).

Penelitian ini dilakukan atas dasar permasalahan di atas dan bertujuan untuk menganalisis sisa makanan lunak rumah sakit pada penyelenggaraan makanan dengan sistem outsourcing di RSUD Gunung Jati Kota Cirebon.

\section{BAHAN DAN METODE}

Penelitian ini menggunakan rancangan cross sectional yang dilaksanakan mulai bulan Oktober sampai Desember 2006 di RSUD Gunung Jati Cirebon. Populasi penelitian adalah pasien yang sedang menjalani rawat inap. Responden dipilih berdasarkan kriteria: berusia di atas 17 tahun, dalam perawatan minimal $2 \times 24$ jam, dapat berkomunikasi dengan baik, mendapat makanan lunak nondiet, tidak mengalami anoreksia, tidak mempunyai gejala gangguan jiwa, tidak dalam perawatan ICU (intensive care unit) dan ICCU (intensive cardio care unit).

Jumlah responden minimal dihitung berdasarkan rumus pendugaan proporsi populasi untuk satu responden, dengan nilai $Z \alpha=1,96(\alpha=0,05), Q=0,4$, dan nilai $d=0,1$, sehingga dibutuhkan sampel minimal sebanyak 93 pasien (8). Responden diambil secara proporsional berdasarkan rata-rata permintaan makanan lunak per hari pada bulan Agustus 2006 dengan proporsi kelas paviliun sebesar 28\%
(26 orang), kelas I sebesar $12 \%$ (11 orang), kelas II sebesar $22 \%$ ( 21 orang), dan kelas III sebesar 38\% (35 orang). Teknik pengambilan responden yang digunakan yaitu purposive sampling.

Alat pengumpulan data yang digunakan antara lain: kuesioner data karakteristik responden, data mutu makanan dan data selera makan, formulir untuk mencatat berat awal makanan sebelum disajikan, formulir skala Comstock 6 poin, formulir pengamatan sisa makanan, serta formulir untuk menghitung biaya makan yang hilang.

Data yang diperoleh selanjutnya diedit secara manual dan dilakukan pengolahan data menggunakan program komputer. Penyajian hasil analisis dalam bentuk analisis univariat untuk menggambarkan karakteristik responden dan biaya makan yang hilang. Analisis bivariat digunakan untuk mengetahui faktor-faktor yang berhubungan dengan terjadinya sisa makanan lunak, hubungan kepuasan responden mengenai mutu makanan dengan sisa makanan lunak, dan hubungan ketidaksesuaian berat porsi makanan lunak yang disajikan terhadap standar berat porsi makanan lunak rumah sakit dengan sisa makanan lunak menggunakan uji chisquare.

\section{HASIL}

\section{Karakteristik responden penelitian}

Karakteristik responden penelitian secara lengkap disajikan pada Tabel 1. Jumlah responden pada penelitian ini adalah 93 orang yang tersebar dalam 4 kelas perawatan di RSUD Gunung Jati Cirebon; yang terbanyak dirawat di kelas III yaitu sebesar $35(37,63 \%)$ orang dan yang paling sedikit dirawat di kelas perawatan I yaitu sebanyak $11(1,07 \%)$ orang.

Sebagian besar responden berjenis kelamin laki-laki yaitu sebanyak $54(58,06 \%)$ orang, demikian pula dengan

TABEL 1. Karakteristik responden penelitian

\begin{tabular}{|c|c|c|c|c|c|c|c|c|c|c|}
\hline \multirow{3}{*}{ Variabel } & \multicolumn{8}{|c|}{ Kelas perawatan } & \multirow{2}{*}{\multicolumn{2}{|c|}{ Jumlah }} \\
\hline & \multicolumn{2}{|c|}{ Paviliun } & \multicolumn{2}{|c|}{ Kelas I } & \multicolumn{2}{|c|}{ Kelas II } & \multicolumn{2}{|c|}{ Kelas III } & & \\
\hline & $\mathbf{n}$ & $\%$ & $\mathbf{n}$ & $\%$ & $\mathbf{n}$ & $\%$ & $\mathbf{n}$ & $\%$ & $\mathbf{n}$ & $\%$ \\
\hline \multicolumn{11}{|l|}{ Jenis kelamin } \\
\hline Laki-Laki & 11 & 42,31 & 8 & 72,73 & 14 & 66,67 & 21 & 60,00 & 54 & 58,06 \\
\hline Perempuan & 15 & 57,69 & 3 & 27,27 & 7 & 33,33 & 14 & 40,00 & 39 & 41,94 \\
\hline \multicolumn{11}{|l|}{ Umur (tahun) } \\
\hline $17-25$ & 8 & 30,77 & 4 & 36,36 & 4 & 19,05 & 7 & 20,00 & 23 & 24,73 \\
\hline $26-35$ & 4 & 15,98 & 1 & 9,09 & 3 & 14,29 & 4 & 11,43 & 12 & 12,90 \\
\hline $36-45$ & 6 & 23,08 & 2 & 18,18 & 6 & 28,57 & 12 & 34,29 & 26 & 27,96 \\
\hline $46-55$ & 6 & 23,08 & 1 & 9,09 & 6 & 28,57 & 7 & 20,00 & 20 & 21,51 \\
\hline$\geq 56$ & 2 & 7,69 & 3 & 27,28 & 2 & 9,52 & 5 & 14,28 & 12 & 12,90 \\
\hline \multicolumn{11}{|l|}{ Peñdidikan } \\
\hline$<$ SLTP & 1 & 3,85 & 2 & 18,18 & 2 & 9,52 & 4 & 11,43 & 9 & 9,68 \\
\hline SLTP & 5 & 19,23 & 4 & 36,36 & 8 & 38,09 & 11 & 31,43 & 28 & 30,11 \\
\hline$>$ SLTP & 20 & 76,92 & 5 & 45,46 & 11 & 52,38 & 20 & 57,14 & 56 & 60,21 \\
\hline \multicolumn{11}{|l|}{ Penyakit } \\
\hline Infeksi & 7 & 26,92 & 2 & 18,18 & 5 & 23,81 & 9 & 25,71 & 23 & 24,73 \\
\hline Noninfeksi & 19 & 73,08 & 9 & 81,82 & 16 & 76,19 & 26 & 74,29 & 70 & 75,27 \\
\hline
\end{tabular}


responden yang berada pada kelas perawatan I, II, dan III yang menunjukkan lebih banyak responden laki-laki daripada perempuan, kecuali untuk kelas paviliun.

Responden berumur antara 17 sampai 62 tahun dan yang terbanyak terdapat pada kelompok umur 36-45 tahun yaitu sebanyak $26(27,96 \%)$ orang.Sebagian besar responden memiliki tingkat pendidikan di atas SLTP (sekolah lanjutan tingkat pertama), yaitu sebanyak $56(60,21 \%)$ orang.

Responden lebih banyak yang menderita penyakit noninfeksi yaitu sebanyak $70(75,27 \%)$ orang dibandingkan penyakit infeksi sebanyak $23(24,73 \%)$ orang. Penyakit responden selama penelitian yang tergolong noninfeksi meliputi: post partum, post operasi tanpa sepsis, eklamsi, dan cedera; sedangkan penyakit infeksi yang diderita responden antara lain: post operasi dengan sepsis, DHF (dengue hemorrhagic fever), febris, luka bakar, dan ISPA (infeksi saluran pernafasan akut).

\section{Faktor-faktor yang berhubungan dengan terjadinya sisa makanan lunak}

Sisa makanan pokok, lauk hewani, lauk nabati, dan sayur Beberapa faktor yang diduga berhubungan dengan terjadinya sisa makanan lunak, antara lain: jenis kelamin, umur, tingkat pendidikan, jenis penyakit, kelas perawatan, dan selera makan. Hasil penelitian mengenai hubungan antara faktor-faktor tersebut dengan sisa makanan pokok, lauk hewani, lauk nabati, dan sayur di rumah sakit dapat dilihat pada Tabel 2.

Dilihat dari jenis kelaminnya, makanan yang tersisa dalam jumlah banyak (> 25\%) ditemukan pada responden laki-laki, terutama untuk makanan pokok $(72,22 \%)$ dan lauk nabati $(70,37 \%)$. Hasil uji chi square menunjukkan hubungan yang bermakna antara jenis kelamin dengan sisa makanan hanya pada sisa lauk nabati $(p<0,05)$.

Dari Tabel 2 juga dapat diketahui bahwa persentase responden dengan sisa makanan pokok dalam jumlah $>$ $25 \%$ paling banyak ditemukan pada kelompok umur $\geq 56$ tahun $(75 \%)$, sedangkan persentase responden dengan sisa lauk hewani, lauk nabati, dan sayur dalam jumlah > $25 \%$ paling banyak ditemukan pada kelompok umur 36-45 tahun dengan persentase berturut-turut 42,31\%, 76,92\%, dan $34,62 \%$. Walaupun demikian, hasil uji statistik membuktikan tidak ada hubungan antara umur dengan terjadinya sisa makanan responden untuk semua jenis hidangan yang diteliti $(p>0,05)$.

Faktor tingkat pendidikan pada penelitian ini ditemukan tidak berhubungan bermakna pada sebagian besar sisa jenis hidangan rumah sakit $(p>0,05)$, kecuali untuk lauk nabati dengan nilai $p=0,025$. Persentase responden yang banyak menyisakan lauk nabati (> 25\%) terlihat paling tinggi pada kelompok dengan tingkat pendidikan SLTP, yaitu sebanyak $82,14 \%$. Sebaliknya, responden yang sedikit menyisakan lauk nabati $(\leq 25 \%)$ terlihat paling tinggi pada responden dengan tingkat pendidikan di atas SLTP, yaitu sebanyak $48,21 \%$.

Berdasarkan hasil uji statistik, sebagian besar sisa makanan lunak pada penelitian ini juga ditemukan berhubungan tidak bermakna dengan jenis penyakit $(p>0,05)$. Hanya sisa makanan pokok yang ditemukan berhubungan bermakna dengan jenis penyakit ( $p=0,013$ ). Sisa makanan pokok dengan jumlah > 25\% ditemukan paling banyak pada kelompok dengan penyakit infeksi (91,30\%), sebaliknya sisa makanan pokok sebesar $\leq 25 \%$ paling banyak ditemukan pada kelompok penyakit noninfeksi $(35,71 \%)$.

Antara kelas perawatan dengan semua sisa makanan lunak yang diteliti juga diperoleh hasil tidak berhubungan bermakna $(p>0,05)$. Dapat dilihat bahwa persentase sisa makanan pokok sebesar $>25 \%$ paling banyak terdapat pada pasien di kelas perawatan III $(74,29 \%)$, namun berbeda dengan sisa lauk hewani sejumlah $>25 \%$ ditemukan terbanyak ada di kelas perawatan I (36,36\%). Pada kelas paviliun dijumpai paling banyak sisa lauk nabati dan sayur dengan jumlah > $25 \%$, masing-masing sebesar $76,92 \%$ dan $42,31 \%$.

Berdasarkan selera makan pasien dapat dilihat bahwa ada hubungan yang bermakna antara selera makan dengan terjadinya sisa makanan pokok dan lauk nabati $(p<0,05)$. Sisa makanan pokok paling banyak ditemui pada kelompok yang tidak memiliki selera makan, yaitu sebanyak $76,56 \%$, begitu pula sisa lauk nabati dengan persentase responden yang tidak berselera makan sebesar $66,67 \%$.

Sisa buah, minuman, dan makanan ringan Hubungan antara faktor jenis kelamin, umur, tingkat pendidikan, jenis penyakit, kelas perawatan, dan selera makan dengan sisa buah, minuman, dan makanan ringan dapat dilihat pada Tabel 3. Dari tabel tersebut diketahui hanya faktor tingkat pendidikan saja yang mempunyai hubungan bermakna dengan terjadinya sisa buah $(p<0,05)$. Sisa buah dengan jumlah banyak ( $>25 \%$ ) paling banyak ditemui pada responden dengan tingkat pendidikan $<$ SLTP.

Pada penelitian ini, minuman dan makanan ringan sebagian besar tidak dijumpai sisa sebanyak $>25 \%$. Hal ini berarti minuman dan makanan ringan dianggap selalu habis atau tidak ada sisanya.

\section{Hubungan kepuasan responden mengenai mutu makanan dengan terjadinya sisa makanan lunak}

Sisa makanan pokok, lauk hewani, lauk nabati, dan sayur Pada penelitian ini, tidak satu pun di antara sisa makanan pokok, lauk hewani, lauk nabati, dan sayur yang berhubungan dengan kepuasan responden mengenai mutu makanan tersebut $(p>0,05)$. Hasil lebih lengkap mengenai hubungan tersebut dapat dilihat pada Tabel 4. Walaupun demikian, dapat diketahui besarnya responden yang menyatakan puas dengan sisa $>25 \%$ makanan pokok, lauk hewani, lauk nabati, dan sayur berturut-turut adalah $70 \%$, $34,62 \%, 54,29 \%$, dan $40,43 \%$. 
TABEL 2. Distribusi faktor-faktor yang berhubungan dengan terjadinya sisa makanan pokok, lauk hewani, lauk nabati, dan sayur

\begin{tabular}{|c|c|c|c|c|c|c|c|c|c|c|c|c|}
\hline \multirow{4}{*}{ Variabel } & \multicolumn{12}{|c|}{ Sisa makanan } \\
\hline & \multicolumn{3}{|c|}{ Makanan pokok } & \multicolumn{3}{|c|}{ Lauk hewani } & \multicolumn{3}{|c|}{ Lauk nabati } & \multicolumn{3}{|c|}{ Sayur } \\
\hline & $\leq 25 \%$ & $>25 \%$ & $p$ & $\leq 25 \%$ & $>25 \%$ & n & $\leq 25 \%$ & $>25 \%$ & p & $\leq 25 \%$ & $>25 \%$ & p \\
\hline & n (\%) & n (\%) & & n (\%) & n (\%) & & n (\%) & n (\%) & & n (\%) & n (\%) & \\
\hline \multicolumn{13}{|l|}{ Jenis kelamin } \\
\hline Laki-laki & $\begin{array}{c}15 \\
(27,78)\end{array}$ & $\begin{array}{c}39 \\
(72,22)\end{array}$ & 0,754 & $\begin{array}{c}35 \\
(64,81)\end{array}$ & $\begin{array}{c}19 \\
(35,19)\end{array}$ & 4,477 & $\begin{array}{c}16 \\
(29,63)\end{array}$ & $\begin{array}{c}38 \\
(70.37)\end{array}$ & $0,034^{*}$ & $\begin{array}{c}42 \\
(77,78)\end{array}$ & $\begin{array}{c}12 \\
(22,22)\end{array}$ & 0,051 \\
\hline Perempuan & $\begin{array}{c}12 \\
(30,77)\end{array}$ & $\begin{array}{c}27 \\
(69,23)\end{array}$ & & $\begin{array}{c}28 \\
(71,79)\end{array}$ & $\begin{array}{c}11 \\
(28,21)\end{array}$ & & $\begin{array}{c}20 \\
(51,28)\end{array}$ & $\begin{array}{c}19 \\
(48,72)\end{array}$ & & $\begin{array}{c}23 \\
(58,97)\end{array}$ & $\begin{array}{c}16 \\
(41,03)\end{array}$ & \\
\hline \multicolumn{13}{|l|}{ Umur (tahun) } \\
\hline $17-25$ & $\begin{array}{c}6 \\
(26,09)\end{array}$ & $\begin{array}{c}17 \\
(73,91)\end{array}$ & 0,880 & $\begin{array}{c}16 \\
(69,57)\end{array}$ & $\begin{array}{c}7 \\
(30,43)\end{array}$ & 0,296 & $\begin{array}{c}10 \\
(43,48)\end{array}$ & $\begin{array}{c}13 \\
(56,52)\end{array}$ & 0,186 & $\begin{array}{c}18 \\
(78,26)\end{array}$ & $\begin{array}{c}5 \\
(21,74)\end{array}$ & 0,453 \\
\hline $26-35$ & $\begin{array}{c}5 \\
(41,67)\end{array}$ & $\begin{array}{c}7 \\
(56,33)\end{array}$ & & $\begin{array}{c}11 \\
(91,67)\end{array}$ & $\begin{array}{c}1 \\
(8,33)\end{array}$ & & $\begin{array}{c}7 \\
(58,33)\end{array}$ & $\begin{array}{c}5 \\
(41,67)\end{array}$ & & $\begin{array}{c}6 \\
(50)\end{array}$ & $\begin{array}{c}6 \\
(50)\end{array}$ & \\
\hline $36-45$ & $\begin{array}{c}7 \\
(26,92)\end{array}$ & $\begin{array}{c}19 \\
(73,08)\end{array}$ & & $\begin{array}{c}15 \\
(57,69)\end{array}$ & $\begin{array}{c}11 \\
(42,31)\end{array}$ & & $\begin{array}{c}6 \\
(23,08)\end{array}$ & $\begin{array}{c}20 \\
(76,92)\end{array}$ & & $\begin{array}{c}17 \\
(65,38)\end{array}$ & $\begin{array}{c}9 \\
(34,62)\end{array}$ & \\
\hline $46-55$ & $\begin{array}{c}6 \\
(30)\end{array}$ & $\begin{array}{c}14 \\
(70)\end{array}$ & & $\begin{array}{c}14 \\
(70)\end{array}$ & $\begin{array}{c}6 \\
(30)\end{array}$ & & $\begin{array}{c}9 \\
(45)\end{array}$ & $\begin{array}{c}11 \\
(55)\end{array}$ & & $\begin{array}{c}15 \\
(75)\end{array}$ & $\begin{array}{c}5 \\
(25)\end{array}$ & \\
\hline$\geq 56$ & $\begin{array}{c}3 \\
(25)\end{array}$ & $\begin{array}{c}9 \\
(75)\end{array}$ & & $\begin{array}{c}7 \\
(58,33)\end{array}$ & $\begin{array}{c}5 \\
(41,67)\end{array}$ & & $\begin{array}{c}4 \\
(33,33)\end{array}$ & $\begin{array}{c}8 \\
(66,67)\end{array}$ & & $\begin{array}{c}9 \\
(75)\end{array}$ & $\begin{array}{c}3 \\
(25)\end{array}$ & \\
\hline \multicolumn{13}{|l|}{ Pendidikan } \\
\hline$<$ SLTP & $\begin{array}{c}3 \\
(33,33)\end{array}$ & $\begin{array}{c}6 \\
(66,67)\end{array}$ & 0,956 & $\begin{array}{c}7 \\
(77,78)\end{array}$ & $\begin{array}{c}2 \\
(22,22)\end{array}$ & 0,153 & $\begin{array}{c}4 \\
(44,44)\end{array}$ & $\begin{array}{c}5 \\
(55.56)\end{array}$ & $0,025^{*}$ & $\begin{array}{c}8 \\
(88,89)\end{array}$ & $\begin{array}{c}1 \\
(11,11)\end{array}$ & 0,256 \\
\hline SLTP & $\begin{array}{c}8 \\
(28,57)\end{array}$ & $\begin{array}{c}20 \\
(71,43)\end{array}$ & & $\begin{array}{c}15 \\
(53,57)\end{array}$ & $\begin{array}{c}13 \\
(46,43)\end{array}$ & & $\begin{array}{c}5 \\
(17,86)\end{array}$ & $\begin{array}{c}23 \\
(82,14)\end{array}$ & & $\begin{array}{c}21 \\
(75)\end{array}$ & $\begin{array}{c}7 \\
(25)\end{array}$ & \\
\hline$>$ SLTP & $\begin{array}{c}16 \\
(28,57)\end{array}$ & $\begin{array}{c}40 \\
(71,43)\end{array}$ & & $\begin{array}{c}41 \\
(73,21)\end{array}$ & $\begin{array}{c}15 \\
(26,79)\end{array}$ & & $\begin{array}{c}27 \\
(48,21)\end{array}$ & $\begin{array}{c}29 \\
(51,79)\end{array}$ & & $\begin{array}{c}36 \\
(64,29)\end{array}$ & $\begin{array}{c}20 \\
(35,71)\end{array}$ & \\
\hline \multicolumn{13}{|l|}{ Jenis penyakit } \\
\hline Infeksi & $\begin{array}{c}2 \\
(8,70)\end{array}$ & $\begin{array}{c}21 \\
(91,30)\end{array}$ & $0,013^{*}$ & $\begin{array}{c}14 \\
(60,87)\end{array}$ & $\begin{array}{c}9 \\
(39,13)\end{array}$ & 0,416 & $\begin{array}{c}10 \\
(43,48)\end{array}$ & $\begin{array}{c}13 \\
(56,52)\end{array}$ & 0,588 & $\begin{array}{c}18 \\
(78,26)\end{array}$ & $\begin{array}{c}5 \\
(21,74)\end{array}$ & 0,313 \\
\hline Noninfeksi & $\begin{array}{c}25 \\
(35,71)\end{array}$ & $\begin{array}{c}45 \\
(64,29)\end{array}$ & & $\begin{array}{c}49 \\
(70,00)\end{array}$ & $\begin{array}{c}21 \\
(30,00)\end{array}$ & & $\begin{array}{c}26 \\
(37,14)\end{array}$ & $\begin{array}{c}44 \\
(62,86)\end{array}$ & & $\begin{array}{c}47 \\
(67,14)\end{array}$ & $\begin{array}{c}23 \\
(32,86)\end{array}$ & \\
\hline \multicolumn{13}{|l|}{ Kelas perawatan } \\
\hline Paviliun & $\begin{array}{c}7 \\
(26,92)\end{array}$ & $\begin{array}{c}19 \\
(73,08)\end{array}$ & 0,640 & $\begin{array}{c}18 \\
(69,23)\end{array}$ & $\begin{array}{c}8 \\
(30,77)\end{array}$ & 0,988 & $\begin{array}{c}6 \\
(23,08)\end{array}$ & $\begin{array}{c}20 \\
(76,92)\end{array}$ & 0,288 & $\begin{array}{c}15 \\
(57,69)\end{array}$ & $\begin{array}{c}11 \\
(42,31)\end{array}$ & 0,178 \\
\hline Kelas I & $\begin{array}{c}5 \\
(45,45)\end{array}$ & $\begin{array}{c}6 \\
(54,55)\end{array}$ & & $\begin{array}{c}7 \\
(63,64)\end{array}$ & $\begin{array}{c}4 \\
(36,36)\end{array}$ & & $\begin{array}{c}5 \\
(45,45)\end{array}$ & $\begin{array}{c}6 \\
(54,55)\end{array}$ & & $\begin{array}{c}9 \\
(81,82)\end{array}$ & $\begin{array}{c}2 \\
(18,18)\end{array}$ & \\
\hline Kelas II & $\begin{array}{c}6 \\
(28,57)\end{array}$ & $\begin{array}{c}15 \\
(71,43)\end{array}$ & & $\begin{array}{c}14 \\
(66,67)\end{array}$ & $\begin{array}{c}7 \\
(33,33)\end{array}$ & & $\begin{array}{c}9 \\
(42,86)\end{array}$ & $\begin{array}{c}12 \\
(57,14)\end{array}$ & & $\begin{array}{c}13 \\
(61,91)\end{array}$ & $\begin{array}{c}8 \\
(38,09)\end{array}$ & \\
\hline Kelas III & $\begin{array}{c}9 \\
(25,71)\end{array}$ & $\begin{array}{c}26 \\
(74,29)\end{array}$ & & $\begin{array}{c}24 \\
(68,57)\end{array}$ & $\begin{array}{c}11 \\
(31,43)\end{array}$ & & $\begin{array}{c}16 \\
(45,71)\end{array}$ & $\begin{array}{c}19 \\
(54,29)\end{array}$ & & $\begin{array}{c}28 \\
(80,00)\end{array}$ & $\begin{array}{c}7 \\
(20,00)\end{array}$ & \\
\hline \multicolumn{13}{|l|}{ Selera makan } \\
\hline Selera & $\begin{array}{c}13 \\
(44,83)\end{array}$ & $\begin{array}{c}16 \\
(55,17)\end{array}$ & $0,045^{\star}$ & $\begin{array}{c}29 \\
(76,32)\end{array}$ & $\begin{array}{c}9 \\
(23,68)\end{array}$ & 0,612 & $\begin{array}{c}18 \\
(54,55)\end{array}$ & $\begin{array}{c}15 \\
(45,45)\end{array}$ & $0,041^{*}$ & $\begin{array}{c}31 \\
(77,50)\end{array}$ & $\begin{array}{c}9 \\
(22,50)\end{array}$ & 0,244 \\
\hline Tidak selera & $\begin{array}{c}15 \\
(23,44)\end{array}$ & $\begin{array}{c}49 \\
(76,56)\end{array}$ & & $\begin{array}{c}35 \\
(63,64)\end{array}$ & $\begin{array}{c}20 \\
(36,36)\end{array}$ & & $\begin{array}{c}20 \\
(33,33)\end{array}$ & $\begin{array}{c}40 \\
(66,67)\end{array}$ & & $\begin{array}{c}36 \\
(67,92)\end{array}$ & $\begin{array}{c}17 \\
(32,08)\end{array}$ & \\
\hline
\end{tabular}

Keterangan:

* Bermakna ( $p<0,05$; uji chi square)

Sisa buah, minuman, dan makanan ringan Sisa buah, minuman, dan makanan ringan juga terbukti tidak berhubungan dengan kepuasan responden mengenai mutu makanan tersebut $(p>0,05)$. Walaupun demikian, seluruh responden $(100 \%)$ yang menyatakan puas terhadap mutu makanan ringan mempunyai sisa makanan ringan berkategori baik $(\leq 25 \%)$ (Tabel 5$)$.
Sisa makanan lunak menurut waktu makan

Dilihat dari waktu makannya, rata-rata persentase sisa makanan lunak terbanyak dijumpai pada waktu sore hari. Makanan lunak yang paling banyak tersisa pada waktu tersebut adalah makanan pokok sebesar $32,21 \%$, lauk hewani sebesar $24,53 \%$, lauk nabati sebesar $35,49 \%$, dan sayur sebesar $18,62 \%$. 
TABEL 3. Distribusi faktor-faktor yang berhubungan dengan terjadinya sisa buah, minuman, dan makanan ringan

\begin{tabular}{|c|c|c|c|c|c|c|c|c|c|}
\hline \multirow{3}{*}{ Variabel } & \multicolumn{9}{|c|}{ Sisa makanan } \\
\hline & \multicolumn{3}{|c|}{ Buah } & \multicolumn{3}{|c|}{ Minuman } & \multicolumn{3}{|c|}{ Makanan ringan } \\
\hline & $\begin{array}{c}\leq \mathbf{2 5 \%} \\
\mathrm{n}(\%) \\
\end{array}$ & $\begin{array}{l}>25 \% \\
\text { n (\%) }\end{array}$ & $\mathbf{p}$ & $\begin{array}{c}\leq \mathbf{2 5 \%} \\
\mathrm{n}(\%)\end{array}$ & $\begin{array}{l}>25 \% \\
\text { n (\%) }\end{array}$ & $\mathbf{p}$ & $\begin{array}{l}\leq 25 \% \\
n(\%)\end{array}$ & $\begin{array}{l}25 \% \\
\text { n (\%) }\end{array}$ & $\mathbf{p}$ \\
\hline \multicolumn{10}{|l|}{ Jenis kelamin } \\
\hline Perempuan & $\begin{array}{c}47 \\
(87,04) \\
35 \\
(89,74)\end{array}$ & $\begin{array}{c}7 \\
(12,96) \\
4 \\
(10,26)\end{array}$ & 0,690 & $\begin{array}{c}54 \\
(100) \\
37 \\
(97,87)\end{array}$ & $\begin{array}{c}0 \\
(0) \\
2 \\
(5,13)\end{array}$ & - & $\begin{array}{c}54 \\
(100) \\
39 \\
(100)\end{array}$ & $\begin{array}{c}0 \\
(0) \\
0 \\
(0)\end{array}$ & - \\
\hline \multicolumn{10}{|l|}{ Umur (tahun) } \\
\hline $26-35$ & $\begin{array}{c}22 \\
(95,65) \\
10 \\
(83,33)\end{array}$ & $\begin{array}{c}1 \\
(4,35) \\
2 \\
(16,67)\end{array}$ & 0,120 & $\begin{array}{c}23 \\
(100) \\
12 \\
(100)\end{array}$ & $\begin{array}{c}0 \\
(0) \\
0 \\
(0)\end{array}$ & - & $\begin{array}{c}23 \\
(100) \\
12 \\
(100)\end{array}$ & $\begin{array}{c}0 \\
(0) \\
0 \\
(0)\end{array}$ & - \\
\hline $36-45$ & $\begin{array}{c}24 \\
(92,31)\end{array}$ & $\begin{array}{c}2 \\
(7,69)\end{array}$ & & $\begin{array}{c}25 \\
(96,15)\end{array}$ & $\begin{array}{c}1 \\
(3,85)\end{array}$ & & $\begin{array}{c}26 \\
(100)\end{array}$ & $\begin{array}{c}0 \\
(0)\end{array}$ & \\
\hline $46-55$ & $\begin{array}{c}18 \\
(90)\end{array}$ & $\begin{array}{c}2 \\
(10)\end{array}$ & & $\begin{array}{c}20 \\
(100)\end{array}$ & $\begin{array}{c}0 \\
(0)\end{array}$ & & $\begin{array}{c}20 \\
(100)\end{array}$ & $\begin{array}{c}0 \\
(0)\end{array}$ & \\
\hline$\geq 56$ & $\begin{array}{c}8 \\
(66,67)\end{array}$ & $\begin{array}{c}4 \\
(33,33)\end{array}$ & & $\begin{array}{c}11 \\
(91,67)\end{array}$ & $\begin{array}{c}1 \\
(8,33)\end{array}$ & & $\begin{array}{c}12 \\
(100)\end{array}$ & $\begin{array}{c}0 \\
(0)\end{array}$ & \\
\hline \multicolumn{10}{|l|}{ Pendidikan } \\
\hline$<$ SLTP & $\begin{array}{c}4 \\
(44,44)\end{array}$ & $\begin{array}{c}5 \\
(55,56)\end{array}$ & $0,000^{*}$ & $\begin{array}{c}9 \\
(100)\end{array}$ & $\begin{array}{c}0 \\
(0)\end{array}$ & - & $\begin{array}{c}9 \\
(100)\end{array}$ & $\begin{array}{c}0 \\
(0)\end{array}$ & - \\
\hline SLTP & $\begin{array}{c}26 \\
(92,86)\end{array}$ & $\begin{array}{c}2 \\
(7,14)\end{array}$ & & $\begin{array}{c}27 \\
(96,43)\end{array}$ & $\begin{array}{c}1 \\
(3,57)\end{array}$ & & $\begin{array}{c}28 \\
(100)\end{array}$ & $\begin{array}{c}0 \\
(0)\end{array}$ & \\
\hline > SLTP & $\begin{array}{c}52 \\
(92,86)\end{array}$ & $\begin{array}{c}4 \\
(7,14)\end{array}$ & & $\begin{array}{c}55 \\
(98,21)\end{array}$ & $\begin{array}{c}1 \\
(1,79)\end{array}$ & & $\begin{array}{c}56 \\
(100)\end{array}$ & $\begin{array}{l}0 \\
(0)\end{array}$ & \\
\hline \multicolumn{10}{|l|}{ Jenis penyakit } \\
\hline Infeksi & $\begin{array}{c}20 \\
(86,96)\end{array}$ & $\begin{array}{c}3 \\
(13,04)\end{array}$ & 0,835 & $\begin{array}{c}23 \\
(100)\end{array}$ & $\begin{array}{c}0 \\
(0)\end{array}$ & - & $\begin{array}{c}23 \\
(100)\end{array}$ & $\begin{array}{c}0 \\
(0)\end{array}$ & - \\
\hline Noninfeksi & $\begin{array}{c}62 \\
(88,57)\end{array}$ & $\begin{array}{c}8 \\
(11,43)\end{array}$ & & $\begin{array}{c}68 \\
(97,14)\end{array}$ & $\begin{array}{c}2 \\
(2,86)\end{array}$ & & $\begin{array}{c}70 \\
(100)\end{array}$ & $\begin{array}{l}0 \\
(0)\end{array}$ & \\
\hline \multicolumn{10}{|l|}{ Kelas perawatan } \\
\hline Paviliun & $\begin{array}{c}22 \\
(84,62)\end{array}$ & $\begin{array}{c}4 \\
(15,38)\end{array}$ & 0,441 & $\begin{array}{c}24 \\
(92,31)\end{array}$ & $\begin{array}{c}2 \\
(7,69)\end{array}$ & - & $\begin{array}{c}26 \\
(100)\end{array}$ & $\begin{array}{c}0 \\
(0)\end{array}$ & - \\
\hline Kelas I & $\begin{array}{c}10 \\
(90,91)\end{array}$ & $\begin{array}{c}1 \\
(9,09)\end{array}$ & & $\begin{array}{c}121 \\
(100)\end{array}$ & $\begin{array}{c}0 \\
(0)\end{array}$ & & $\begin{array}{c}11 \\
(100)\end{array}$ & $\begin{array}{c}0 \\
(0)\end{array}$ & \\
\hline Kelas II & $\begin{array}{c}17 \\
(80,95)\end{array}$ & $\begin{array}{c}4 \\
(19,05)\end{array}$ & & $\begin{array}{c}21 \\
(100)\end{array}$ & $\begin{array}{l}0 \\
(0)\end{array}$ & & $\begin{array}{c}21 \\
(100)\end{array}$ & $\begin{array}{c}0 \\
(0)\end{array}$ & \\
\hline Kelas III & $\begin{array}{c}33 \\
(94,29)\end{array}$ & $\begin{array}{c}2 \\
(5,71)\end{array}$ & & $\begin{array}{c}35 \\
(100)\end{array}$ & $\begin{array}{c}0 \\
(0)\end{array}$ & & $\begin{array}{c}35 \\
(100)\end{array}$ & $\begin{array}{c}0 \\
(0)\end{array}$ & \\
\hline \multicolumn{10}{|l|}{ Selera makan } \\
\hline Selera & $\begin{array}{c}48 \\
(87,27)\end{array}$ & $\begin{array}{c}7 \\
(12,73)\end{array}$ & 0,817 & $\begin{array}{c}91 \\
(100)\end{array}$ & $\begin{array}{c}0 \\
(0)\end{array}$ & - & $\begin{array}{c}93 \\
(100)\end{array}$ & $\begin{array}{c}0 \\
(0)\end{array}$ & - \\
\hline Tidak selera & $\begin{array}{c}34 \\
(89,47) \\
\end{array}$ & $\begin{array}{c}4 \\
(10,53) \\
\end{array}$ & & $\begin{array}{c}0 \\
(0) \\
\end{array}$ & $\begin{array}{c}2 \\
(100) \\
\end{array}$ & & $\begin{array}{c}0 \\
(0) \\
\end{array}$ & $\begin{array}{c}0 \\
(0)\end{array}$ & \\
\hline
\end{tabular}

Keterangan:

${ }^{*}$ Bermakna $(p<0,05$; uji chi square $)$

Hubungan ketidaksesuaian berat porsi makanan lunak yang disajikan terhadap standar berat porsi makanan lunak rumah sakit dengan terjadinya sisa makanan lunak

Standar berat porsi makanan pasien yang digunakan merupakan berat bersih atau belum mengalami pengolahan. Standar berat porsi beras (bubur/tim) adalah $60 \mathrm{~g}$, ayam 100 $\mathrm{g}$ (pavilliun) dan $75 \mathrm{~g}$ (I, II dan III), daging sapi $50 \mathrm{~g}$ (paviliun) dan $40 \mathrm{~g}$ (I, II dan III), bandeng segar $75 \mathrm{~g}$, telur ayam/telur asin $60 \mathrm{~g}$, telur puyuh 7 butir (paviliun) dan 5 butir (I, II, dan III), udang $50 \mathrm{~g}$ dan kakap filet $50 \mathrm{~g}$. Standar berat porsi lauk nabati yaitu tahu $100 \mathrm{~g}$ dan tempe $50 \mathrm{~g}$. Standar berat porsi sayuran $100 \mathrm{~g}$ (paviliun) dan $75 \mathrm{~g}$ (I, II, dan III). Standar berat porsi pepaya/semangka/melon $125 \mathrm{~g}$ (paviliun) dan $80 \mathrm{~g}$ (I, II, dan III), apel merah/jeruk/pir 125-150 g (paviliun).

Sisa makanan pokok, lauk hewani, lauk nabati, dan sayur Ketidaksesuaian berat porsi makanan lunak yang disajikan terhadap standar berat porsi makanan lunak rumah sakit serta hubungannya dengan sisa makanan pokok, lauk hewani, lauk nabati, dan sayur dapat dilihat pada Tabel 6. Berdasarkan tabel tersebut diketahui sebagian besar responden, baik yang sisa makanan pokoknya $>25 \%$ maupun 
TABEL 4. Hubungan kepuasan responden mengenai mutu makanan dengan sisa makanan pokok, lauk hewani, lauk nabati, dan sayur

\begin{tabular}{|c|c|c|c|c|c|c|c|c|c|c|c|c|}
\hline \multirow{3}{*}{$\begin{array}{c}\text { Mutu } \\
\text { makanan }\end{array}$} & \multicolumn{12}{|c|}{ Sisa makanan } \\
\hline & \multicolumn{3}{|c|}{ Makanan pokok } & \multicolumn{3}{|c|}{ Lauk hewani } & \multicolumn{3}{|c|}{$\begin{array}{ll}\text { Lauk nabati }\end{array}$} & \multicolumn{3}{|c|}{ Sayur } \\
\hline & $\begin{array}{c}\leq 25 \% \\
n(\%)\end{array}$ & $\begin{array}{r}25 \% \\
n(\%)\end{array}$ & $\mathbf{p}$ & $\begin{array}{r}\leq 25 \% \\
n(\%)\end{array}$ & $\begin{array}{r}>25 \% \\
n(\%)\end{array}$ & $\mathbf{p}$ & $\begin{array}{r}\leq 25 \% \\
n(\%)\end{array}$ & $\begin{array}{r}>25 \% \\
n(\%)\end{array}$ & $\mathbf{p}$ & $\begin{array}{c}\leq 25 \% \\
n(\%)\end{array}$ & $\begin{array}{r}>25 \% \\
\text { n (\%) }\end{array}$ & $\mathbf{p}$ \\
\hline Memuaskan & $\begin{array}{c}12 \\
(30) \\
20\end{array}$ & $\begin{array}{c}28 \\
(70) \\
33\end{array}$ & 0,089 & $\begin{array}{c}34 \\
(65,38) \\
19\end{array}$ & $\begin{array}{c}18 \\
(34,62) \\
22\end{array}$ & 0,059 & $\begin{array}{c}16 \\
(45,71) \\
21\end{array}$ & $\begin{array}{c}19 \\
(54,29) \\
37\end{array}$ & 0,389 & $\begin{array}{c}28 \\
(59,57) \\
31\end{array}$ & $\begin{array}{c}19 \\
(40,43) \\
15\end{array}$ & 0,779 \\
\hline memuaskan & $(37,74)$ & $(62,26)$ & & $(46,34)$ & $(53,66)$ & & $(36,21)$ & $(63,79)$ & & $(67,39)$ & $(32,61)$ & \\
\hline
\end{tabular}

Keterangan:

p (uji chi square)

TABEL 5 . Hubungan kepuasan responden mengenai mutu makanan dengan sisa buah, minuman, dan makanan ringan

\begin{tabular}{|c|c|c|c|c|c|c|c|c|c|}
\hline \multirow{3}{*}{ Mutu makanan } & \multicolumn{9}{|c|}{ Sisa makanan } \\
\hline & \multicolumn{3}{|c|}{ Buah } & \multicolumn{3}{|c|}{ Minuman } & \multicolumn{3}{|c|}{ Makanan ringan } \\
\hline & $\begin{array}{l}\leq 25 \% \\
\mathrm{n}(\%)\end{array}$ & $\begin{array}{c}>25 \% \\
n(\%)\end{array}$ & $\mathbf{p}$ & $\begin{array}{l}\leq 25 \% \\
\mathrm{n}(\%)\end{array}$ & $\begin{array}{c}>25 \% \\
n(\%)\end{array}$ & $\mathbf{p}$ & $\frac{\leq 25 \%}{n(\%)}$ & $\begin{array}{c}>25 \% \\
n(\%)\end{array}$ & $\mathbf{p}$ \\
\hline Memuaskan & 53 & 11 & & 91 & 2 & & 93 & 0 & \\
\hline $\begin{array}{l}\text { Tidak } \\
\text { Memuaskan }\end{array}$ & $\begin{array}{c}(82,81) \\
20 \\
(68.97)\end{array}$ & $\begin{array}{c}(17,19) \\
9 \\
(3103)\end{array}$ & 0,0566 & $\begin{array}{c}(97,85) \\
0 \\
(0)\end{array}$ & $\begin{array}{c}(2,15) \\
0 \\
(0)\end{array}$ & - & $\begin{array}{c}(100) \\
0 \\
(0)\end{array}$ & $\begin{array}{c}(0) \\
0\end{array}$ & - \\
\hline
\end{tabular}

Keterangan:

p (uji chi square)

yang sisa lauk hewaninya $\leq 25 \%$, telah mengkonsumsi makanan pokok dan lauk hewani yang sesuai dengan standar berat porsi makanan rumah sakit $(72,41 \%$ vs $78 \%)$. Namun demikian, sisa lauk nabati sebanyak $>25 \%$ pada sebagian besar responden $(76,92 \%)$ disajikan lebih dari standar berat porsi makanan rumah sakit dan $88,09 \%$ responden dengan sisa sayur $\leq 25 \%$ disajikan dengan berat porsi kurang dari standar. Hasil uji chi square menunjukkan ada hubungan yang bermakna antara ketidaksesuaian berat porsi makanan lunak yang disajikan terhadap standar berat porsi makanan lunak rumah sakit (khususnya berat porsi yang melebihi standar berat porsi makanan rumah sakit) dengan terjadinya sisa makanan $(p<0,05)$.

Sisa buah, minuman, dan makanan ringan Persentase ketidaksesuaian berat porsi buah yang disajikan terhadap standar berat porsi buah rumah sakit dengan terjadinya sisa makanan $>25 \%$ sebesar $23,68 \%$, namun tidak ada responden pada kelompok sisa makanan $>25 \%$ untuk minuman dan makanan ringan, walaupun makanan tersebut disajikan lebih dari standar berat porsi rumah sakit. Hal ini berarti minuman dan makanan ringan dianggap selalu habis atau tidak ada sisanya (Tabel 7 ).

\section{Biaya makan yang hilang}

Biaya sisa makanan lunak diperhitungkan sebagai biaya yang hilang akibat ketidaksesuaian berat porsi makanan lunak yang disajikan kurang dari standar berat porsi makanan lunak rumah sakit pada masing-masing kelas perawatan, sehingga diperoleh hasil rata-rata biaya makan yang hilang setiap responden.

Biaya makan yang hilang per orang dalam sehari menurut kelas perawatan yang terbesar terdapat di kelas paviliun yaitu sebesar Rp 3.698,61,- dan biaya makan yang hilang terkecil dijumpai pada kelas I yaitu sebesar Rp 2.825,76,-. Setelah

TABEL 6. Hubungan ketidaksesuaian berat porsi makanan lunak yang disajikan terhadap standar berat porsi makanan lunak rumah sakit dengan sisa makanan pokok, lauk hewani, lauk nabati, dan sayur

\begin{tabular}{|c|c|c|c|c|c|c|c|c|c|c|c|c|}
\hline \multirow{3}{*}{$\begin{array}{c}\text { Kategori } \\
\text { ketidaksesuaian }\end{array}$} & \multicolumn{12}{|c|}{ Sisa makanan } \\
\hline & \multicolumn{3}{|c|}{ Makanan pokok } & \multicolumn{3}{|c|}{ Lauk hewani } & \multicolumn{3}{|c|}{$\begin{array}{ll}\text { Lauk nabati }\end{array}$} & \multicolumn{3}{|c|}{ Sayur } \\
\hline & $\begin{array}{r}\leq 25 \% \\
n(\%)\end{array}$ & $\begin{array}{c}\mathbf{2 5 \%} \\
\mathrm{n}(\%)\end{array}$ & $\mathbf{p}$ & $\begin{array}{r}\leq 25 \% \\
n(\%)\end{array}$ & $\begin{array}{r}>25 \% \\
n(\%)\end{array}$ & $\mathbf{p}$ & $\begin{array}{r}\leq 25 \% \\
n(\%)\end{array}$ & $\begin{array}{c}25 \% \\
n(\%)\end{array}$ & $\mathbf{p}$ & $\begin{array}{r}\leq 25 \% \\
n(\%)\end{array}$ & $\begin{array}{c}>25 \% \\
\mathrm{n}(\%)\end{array}$ & $\mathbf{p}$ \\
\hline Kurang standar & $\begin{array}{c}7 \\
(31,82)\end{array}$ & $\begin{array}{c}15 \\
(68,18)\end{array}$ & & $\begin{array}{c}16 \\
(69,57)\end{array}$ & $\begin{array}{c}7 \\
(30,43)\end{array}$ & & $\begin{array}{c}11 \\
(61,11)\end{array}$ & $\begin{array}{c}7 \\
(38,89)\end{array}$ & & $\begin{array}{c}37 \\
(88,09)\end{array}$ & $\begin{array}{c}5 \\
(11,91)\end{array}$ & \\
\hline Sesuai standar & $\begin{array}{c}8 \\
(27,59)\end{array}$ & $\begin{array}{c}21 \\
(72,41)\end{array}$ & $0,015^{*}$ & $\begin{array}{c}39 \\
(78,00)\end{array}$ & $\begin{array}{c}11 \\
(22,00)\end{array}$ & $0,018^{*}$ & $\begin{array}{c}21 \\
(42,86)\end{array}$ & $\begin{array}{c}28 \\
(57,14)\end{array}$ & $0,038^{*}$ & $\begin{array}{c}19 \\
(70,37)\end{array}$ & $\begin{array}{c}8 \\
(29,63)\end{array}$ & $0,000^{*}$ \\
\hline Lebih standar & $\begin{array}{c}13 \\
(30,95)\end{array}$ & $\begin{array}{l}29 \\
(69,05)\end{array}$ & & $\begin{array}{c}8 \\
(40,00)\end{array}$ & $\begin{array}{c}12 \\
(60,00)\end{array}$ & & $\begin{array}{c}6 \\
(23,08)\end{array}$ & $\begin{array}{c}20 \\
(76,92)\end{array}$ & & $\begin{array}{c}11 \\
(45,83)\end{array}$ & $\begin{array}{c}13 \\
(54,17)\end{array}$ & \\
\hline
\end{tabular}

Keterangan:

* Bermakna ( $p<0,05$; uji chi square) 
TABEL 7. Hubungan ketidaksesuaian berat porsi makanan lunak yang disajikan terhadap standar berat porsi makanan lunak rumah sakit dengan sisa buah, minuman, dan makanan ringan

\begin{tabular}{|c|c|c|c|c|c|c|c|c|c|}
\hline \multirow{3}{*}{$\begin{array}{c}\text { Kategori } \\
\text { ketidaksesuaian }\end{array}$} & \multicolumn{9}{|c|}{ Sisa makanan } \\
\hline & \multicolumn{3}{|c|}{ Buah } & \multicolumn{3}{|c|}{ Minuman } & \multicolumn{3}{|c|}{ Makanan ringan } \\
\hline & $\frac{\leq 25 \%}{\mathrm{n}(\%)}$ & $\begin{array}{l}>25 \% \\
\text { n (\%) }\end{array}$ & $\mathbf{p}$ & $\begin{array}{l}\frac{\leq 25 \%}{\mathrm{n}(\%)} \\
\end{array}$ & $\begin{array}{l}>25 \% \\
\text { n (\%) }\end{array}$ & $\mathbf{p}$ & $\begin{array}{l}\frac{\leq 25 \%}{n(\%)} \\
\end{array}$ & $\begin{array}{c}>25 \% \\
\text { n (\%) }\end{array}$ & $p$ \\
\hline Kurang standar & $\begin{array}{c}0 \\
(0)\end{array}$ & $\begin{array}{c}0 \\
(0)\end{array}$ & & $\begin{array}{c}0 \\
(0)\end{array}$ & $\begin{array}{c}0 \\
(0)\end{array}$ & & $\begin{array}{c}0 \\
(0)\end{array}$ & $\begin{array}{c}0 \\
(0)\end{array}$ & \\
\hline Sesuai standar & $\begin{array}{c}53 \\
(96,36)\end{array}$ & $\begin{array}{c}2 \\
(3,64)\end{array}$ & - & $\begin{array}{c}91 \\
(97,85)\end{array}$ & $\begin{array}{c}2 \\
(2,15)\end{array}$ & - & $\begin{array}{c}85 \\
(100)\end{array}$ & $\begin{array}{c}0 \\
(0)\end{array}$ & - \\
\hline Lebih standar & $\begin{array}{c}29 \\
(76,32) \\
\end{array}$ & $\begin{array}{c}9 \\
(23,68) \\
\end{array}$ & & $\begin{array}{c}0 \\
(0) \\
\end{array}$ & $\begin{array}{c}0 \\
(0)\end{array}$ & & $\begin{array}{c}8 \\
(100) \\
\end{array}$ & $\begin{array}{c}0 \\
(0)\end{array}$ & \\
\hline
\end{tabular}

Keterangan:

$\mathrm{p}$ (uji chi square)

TABEL 8. Rata-rata biaya makan yang hilang per orang

\begin{tabular}{|c|c|c|c|c|}
\hline $\begin{array}{c}\text { Kelas } \\
\text { perawatan }\end{array}$ & $\begin{array}{l}\text { Biaya } \\
\text { sisa } \\
\text { makanan } \\
\text { sehari } \\
(\mathrm{Rp})\end{array}$ & $\begin{array}{l}\text { Biaya ketidaksesuaian } \\
\text { dengan standar berat porsi } \\
\text { makanan lunak rumah sakit } \\
\text { sehari } \\
(\mathrm{Rp})\end{array}$ & $\begin{array}{l}\text { Biaya makan yang } \\
\text { hilang sehari } \\
\text { (Rp) }\end{array}$ & $\begin{array}{l}\text { Biaya makan } \\
\text { yang hilang } \\
\text { setahun } \\
\text { (Rp) }\end{array}$ \\
\hline Paviliun & $2.506,06$ & $1.192,55$ & $3.698,61$ & $1.349 .992,65$ \\
\hline I & $1.448,52$ & $1.377,24$ & $2.825,76$ & $1.031 .402,40$ \\
\hline II & $1.774,64$ & $1.329,61$ & $3.104,25$ & $1.133 .051,25$ \\
\hline III & $1.569,75$ & $1.360,75$ & $2.930,50$ & $1.069 .632,50$ \\
\hline Total & $7.298,97$ & $5.260,15$ & $12.559,12$ & $4.584 .078,80$ \\
\hline
\end{tabular}

dijumlahkan, total biaya makan yang hilang dalam sehari sebesar Rp 12.559,12,- dan perhitungan dalam setahun akan diperoleh total biaya makan yang hilang sebesar Rp. 4.584.078,80,- (Tabel 8).

\section{BAHASAN}

\section{Faktor-faktor yang berhubungan dengan terjadinya sisa makanan lunak}

Keberhasilan suatu penyelenggaraan makanan di rumah sakit dikaitkan dengan adanya sisa makanan. Sisa makanan yang melebihi $25 \%$ menunjukkan kurang berhasilnya suatu penyelenggaraan makanan di rumah sakit (3).

Jenis kelamin Tidak ada hubungan antara jenis kelamin dengan terjadinya sisa makanan lunak, kecuali pada sisa lauk nabati. Hal ini disebabkan banyaknya jumlah sisa lauk nabati pada responden laki-laki berkaitan dengan frekuensi pengulangan variasi jenis lauk nabati yang termasuk sering dalam waktu yang berdekatan, terutama tahu dan tempe. Hal ini dapat menimbulkan kebosanan makan responden terhadap lauk nabati. Menurut Law dan Gregoire (9), variasi bahan makanan yang disajikan merupakan prediktor pelayanan makan di rumah sakit. Variasi bahan makanan yang baik dapat meningkatkan kualitas makanan yang disajikan dan daya terima makan responden. Hal ini juga sejalan dengan hasil survei kepuasan pasien yang dilakukan di Instalasi Gizi RSUP (Rumah Sakit Umum Pusat) Dr. Sardjito Yogyakarta tahun 2001 mengenai evaluasi hidangan makanan pasien rawat inap yang menunjukkan hasil bahwa lauk nabati seperti tahu dan tempe merupakan makanan yang tidak disukai, namun sebaliknya lauk hewani merupakan makanan yang paling disukai oleh pasien selama dirawat di rumah sakit (10).

Umur Tidak ada hubungan yang bermakna antara umur dengan terjadinya sisa makanan lunak $(p>0,05)$. Hal ini sesuai dengan hasil penelitian Almatsier (7) di seluruh rumah sakit panduan di Indonesia yang menyatakan bahwa tidak ada perbedaan antara persepsi makanan pasien menurut umur.

Tingkat pendidikan Antara tingkat pendidikan dengan terjadinya sisa makanan lunak diketahui ada hubungan yang bermakna pada jenis hidangan lauk nabati dan buah ( $p=$ 0,025 dan 0,000). Hal ini mungkin disebabkan tingkat pendidikan berpengaruh terhadap pengetahuan responden tentang manfaat hidangan yang disajikan oleh rumah sakit. Pasien menganggap buah hanya sebagai makanan pelengkap saja. Kemungkinan adanya sisa lauk nabati disebabkan timbulnya rasa bosan karena frekuensi pengulangan variasi lauk nabati terlalu sering dalam waktu yang berdekatan.

Hal ini sejalan dengan hasil penelitian yang dilakukan oleh Setyowati (11) di RSUP Dr. Sardjito yang menunjukkan adanya perbedaan yang bermakna antara pasien berpendidikan < SLTA (sekolah lanjutan tingkat atas) dan $\geq$ SLTA terhadap asupan 
energi. Pasien dengan pendidikan $\geq$ SLTA lebih memilih hidangan yang disajikan oleh rumah sakit dibandingkan yang berpendidikan < SLTA.

Jenis penyakit Ada hubungan antara jenis penyakit dengan terjadinya sisa makanan lunak pada sisa makanan pokok $(p<0,05)$. Data tersebut menunjukkan bahwa sisa makanan pokok lebih banyak dijumpai pada responden yang menderita penyakit infeksi. Kemungkinan banyaknya sisa makanan pokok karena pasien tidak memiliki selera pada makanan pokok yang disajikan di rumah sakit. Makanan pokok dari rumah sakit (bubur/tim) mempunyai konsistensi yang lebih encer daripada makanan pokok yang dihidangkan di rumah (nasi). Selain itu, kemungkinan hal ini terjadi juga karena pasien mempunyai tingkat stres yang tinggi, baik disebabkan oleh penyakit yang sedang diderita maupun terapi medik yang didapat sehingga mengakibatkan penurunan nafsu makan, aktivitas fisik, dan kondisi mental yang berubah (7).

Pada pasien infeksi sering terjadi gangguan saluran pencernaan, sehingga akan mempengaruhi nafsu makan. Hal ini dipertegas oleh hasil penelitian Dwiyanti et al. (12) di RSUP Dr. Sardjito, RSUP Dr. M. Djamil Padang, dan RSUP Sanglah Denpasar yang menyatakan bahwa ada pengaruh gejala gastrointestinal terhadap asupan makanan pasien selama di rumah sakit. Gangguan gastrointestinal sering ditandai dengan gejala mual, muntah, kembung, tidak nafsu makan, dan diare. Hal ini berakibat makanan lebih banyak yang tidak dikonsumsi oleh pasien dan meninggalkan sisa. Dengan demikian, salah satu penyebab terjadinya sisa makanan adalah faktor penyakit yang diderita responden.

Kelas perawatan Tidak ada hubungan yang bermakna antara kelas perawatan dengan terjadinya sisa semua jenis makanan lunak. Kemungkinan hal tersebut karena tidak adanya perbedaan menu untuk setiap kelas perawatan. Hal ini sejalan dengan hasil penelitian yang dilakukan oleh Almatsier (7) yang menyimpulkan bahwa kelas perawatan ternyata tidak berpengaruh terhadap persepsi pasien atas makanan yang disajikan.

Selera makan Ada hubungan bermakna antara selera makan dengan terjadinya sisa makanan lunak, yaitu pada sisa makanan pokok dan lauk nabati $(p<0,05)$. Dengan demikian dapat diketahui bahwa adanya sisa makanan tersebut disebabkan banyak responden yang tidak memiliki selera pada makanan pokok dan lauk nabati. Hal ini disebabkan makanan pokok (tim/bubur) dan lauk nabati yang diberikan di rumah sakit berbeda dengan kebiasaan makan di rumah (nasi). Teknik pengolahan makanan pokok juga dapat membatasi penggunaan lemak (minyak) dan bumbu sehingga pemasakan lebih sering dengan cara merebus dan menggunakan bumbu yang tidak terlalu tajam. Perbedaan tersebut sangat mempengaruhi selera makan responden.

Menurut Mukrie et al. (6), makanan yang disajikan sesuai dengan kebiasaan makan pasien akan berpengaruh terhadap selera makan pasien. Pasien cenderung akan menghabiskan makanan yang disajikan. Sebaliknya, bila tidak sesuai dengan kebiasaan makan pasien akan menurunkan selera makan pasien, sehingga dibutuhkan waktu untuk menyesuaikannya. Moehji (13) juga mengemukakan bahwa selera makan biasanya sangat dipengaruhi oleh kondisi dan keadaan pasien. Pada umumnya, pasien merasa takut dan sedih karena menderita penyakit dan adanya ketidakbebasan gerak akibat penyakit tertentu. Hal ini sering membuat putus asa yang akhirnya menyebabkan pasien kehilangan selera makan.

\section{Hubungan kepuasan responden mengenai mutu makanan dengan terjadinya sisa makanan lunak}

Tidak ada hubungan yang bermakna antara kepuasan responden mengenai mutu makanan dengan terjadinya sisa semua jenis makanan lunak $(p>0,05)$. Hal ini sejalan dengan penelitian Djamaluddin et al. (14) di RSUP Dr. Sardjito yang menunjukkan tidak ada perbedaan sisa makanan biasa menurut cita rasa makanan. Namun demikian, persentase ketidakpuasan yang terbesar ditemui pada sisa lauk nabati $(63,79 \%)$. Ketidakpuasan tersebut kemungkinan bukan disebabkan oleh rasa makanan akibat tidak ada perbedaan menu setiap kelas perawatan, melainkan disebabkan frekuensi pengulangan variasi lauk nabati sama yang terlalu sering dalam waktu berdekatan, seperti tahu dan tempe. Hal ini dapat menimbulkan kebosanan responden terhadap lauk nabati. Kemungkinan lain penyebab ketidakpuasan tersebut yaitu unsur penampilan makanan. Salah satu unsur penampilan makanan adalah peralatan makan yang digunakan dan ketepatan waktu penyajian.

Pada penelitian ini, rata-rata persentase sisa makanan terbanyak dijumpai pada waktu sore hari, yaitu pada makanan pokok, lauk hewani, lauk nabati, dan sayur. Adanya sisa makanan pada waktu makan sore mungkin disebabkan waktu makan sore di rumah sakit terlalu cepat yaitu pukul 17.00 WIB dibandingkan kebiasaan umum waktu makan sore orang Indonesia yaitu antara pukul $18.00-19.00$ WIB. Hal ini menyebabkan pasien menunda makan karena merasa masih kenyang dan tidak lazim makan sore pada jam tersebut.

Dibandingkan dengan indikator kepuasan pasien (perspektif pelanggan) yang digunakan pada beberapa rumah sakit dengan kisaran puas antara $85-100 \%$, maka kepuasan responden pada penelitian ini dapat dikatakan kurang dengan nilai kisaran $<85 \%$, kecuali pada minuman dan makanan ringan.

\section{Hubungan ketidaksesuaian berat porsi makanan lunak yang disajikan terhadap standar berat porsi makanan lunak rumah sakit dengan terjadinya sisa makanan lunak}

Ada hubungan bermakna antara ketidaksesuaian berat porsi makanan lunak yang disajikan terhadap standar berat porsi makanan lunak rumah sakit dengan terjadinya sisa makanan lunak $(p<0,05)$. Data tersebut menunjukkan bahwa makin besar ketidaksesuaian berat porsi makanan lunak yang disajikan kepada responden terhadap standar berat porsi makanan lunak rumah sakit, makin banyak pula makanan 
yang tersisa. Hal ini berarti kemungkinan standar berat porsi makanan yang diberikan rumah sakit telah sesuai dengan kebutuhan pasien, sehingga bila berat porsi makanan yang disajikan lebih besar dari standar berat porsi makanan rumah sakit akan menyebabkan pasien meninggalkan sisa makanannya akibat porsi yang terlalu banyak. Hal ini sejalan dengan penelitian yang dilakukan Djamaluddin et al. (14) yang menyimpulkan bahwa makanan yang disajikan sesuai dengan standar porsi rumah sakit menyebabkan pasien sedikit meninggalkan sisa makanannya karena porsi hidangan yang diberikan telah sesuai dengan kebutuhan pasien.

Ketidaksesuaian berat porsi makanan yang disajikan terhadap standar berat porsi makanan rumah sakit yang berlangsung lama akan menyebabkan pemberian makanan pada pasien tidak adekuat. Hal ini berakibat mempengaruhi status gizi pasien. Menurut Moehji (13), pemberian makanan yang tidak adekuat dapat berpengaruh pada status gizi sehingga berdampak dalam meningkatkan masalah gizi dan mortalitas. Selain itu, ketidaksesuaian berat porsi makanan yang disajikan tersebut juga dapat menyebabkan adanya biaya makan yang hilang secara sia-sia. Adanya biaya yang hilang menyebabkan anggaran makanan kurang efisien dan efektif, sehingga akan berdampak terhadap biaya atau anggaran yang digunakan untuk pengadaan bahan makanan, khususnya biaya total bahan makanan (7).

Ketidaksesuaian tersebut biasanya terjadi karena tidak adanya prosedur tetap pengawasan makanan pada penyelenggaraan makanan dengan sistem outsourcing, sehingga menyebabkan kurangnya fungsi instalasi gizi dalam mengawasi proses distribusi makanan (quality control). Pengawas makanan memegang peranan kunci dalam pengawasan makanan untuk melindungi pasien dari makanan yang tidak memenuhi standar dan persyaratan bagi kesehatan. Hal tersebut akan mengakibatkan pula adanya anggaran makanan yang kurang efisien (15).

\section{Biaya makan yang hilang}

Pada penelitian ini, total biaya makan per orang yang hilang dalam sehari sebesar $\operatorname{Rp} 12.559,12$,- atau $13,88 \%$ dari total harga makanan (food cost) pasien sehari. Walaupun persentase biaya makan yang hilang masih di bawah $25 \%$ dari harga makanan, tetap menggambarkan anggaran makan yang kurang efisien. Bila diperhitungkan dalam setahun akan diperoleh total biaya makan yang hilang sebesar Rp 4.584.078,80,-. Rata-rata biaya yang hilang setiap responden terlihat paling besar terdapat di kelas paviliun. Hal ini disebabkan harga makanan (food cost) kelas paviliun lebih tinggi dibandingkan kelas perawatan lainnya.

Makin banyak jumlah makanan yang tersisa dan makin tinggi harga makanan, maka biaya sisa makanan juga akan meningkat. Kemungkinan hal tersebut disebabkan besarnya harga satuan dari bahan makanan dan banyaknya makanan yang hilang, baik dari sisa makanan maupun dari ketidaksesuaian berat porsi makanan lunak responden yang kurang dari standar berat porsi makanan lunak rumah sakit.

Besarnya harga satuan bahan makanan dan banyaknya sisa makanan akan mempengaruhi besarnya biaya sisa makanan. Menurut Djamaluddin et al. (14), biaya sisa makanan pokok, lauk nabati, dan sayur yang jumlahnya banyak ternyata lebih murah dibandingkan dengan lauk hewani dan buah yang jumlahnya sedikit. Hal ini disebabkan harga bahan makanan pokok, lauk nabati, dan sayur yang lebih murah bila dibandingkan dengan harga lauk hewani dan buah.

Adanya sisa makanan menunjukkan ketidakefisienan manajemen pelaksanaan sistem penyelenggaraan makanan Analisis biaya makan merupakan salah satu cara untuk mengevaluasi pelayanan gizi yang diberikan, terutama penyelenggaraan makanan yang menyangkut keefektifan dan keefisienan sistem penyelenggaraan makanan yang digunakan pada rumah sakit tersebut.

Dengan adanya analisis biaya makan yang hilang, berarti ada rata-rata biaya makanan yang terbuang. Informasi ini diharapkan dapat memberikan masukan kepada manajemen rumah sakit dalam pengelolaan anggaran makan pasien secara efektif dan efisien. Hal ini sangat penting bagi rumah sakit sebagai upaya memberikan mutu pelayanan yang terbaik dengan tarif yang bersaing.

\section{KESIMPULAN DAN SARAN}

Berdasarkan pembahasan di atas, dapat disimpulkan faktor umur dan kelas perawatan tidak berhubungan dengan terjadinya semua jenis sisa makanan. Sebaliknya, faktor jenis kelamin dan selera makan berhubungan dengan sisa lauk nabati, sedangkan tingkat pendidikan dan jenis penyakit berhubungan dengan sisa makanan pokok. Tidak ada hubungan bermakna antara kepuasan responden mengenai mutu makanan dengan terjadinya semua jenis sisa makanan lunak, namun ditemukan hubungan bermakna antara ketidaksesuaian berat porsi makanan lunak yang disajikan terhadap standar berat porsi makanan lunak rumah sakit dengan terjadinya sisa makanan pokok, lauk hewani, lauk nabati, dan sayur. Total biaya makan yang hilang akibat ketidaksesuaian berat porsi makanan lunak yang disajikan kepada responden dan sisa makanan menurut kelas perawatan per orang sebesar $\operatorname{Rp} 12.559,12$,- dalam sehari atau $\mathrm{Rp}$ 4.584.078,80,- dalam setahun.

Berdasarkan hasil penelitian ini disarankan agar pihak rumah sakit dapat meningkatkan fungsi instalasi gizi dalam pengawasan proses distribusi makanan pada penyelenggaraan makanan dengan sistem outsourcing untuk mengatasi ketidaksesuaian berat porsi makanan lunak yang disajikan terhadap standar berat porsi makanan lunak rumah sakit. Salah satu implementasi peningkatan fungsi tersebut dapat dilakukan dengan menetapkan prosedur tetap pengawasan distribusi makanan. Dalam upaya meningkatkan mutu makanan dan meminimalkan makanan 
yang tersisa, perlu dilakukan pelatihan untuk meningkatkan pengetahuan dan keterampilan di bidang kuliner, variasi, dan teknik pemasakan makanan lunak. Adanya sisa makanan, biaya makan yang hilang, belum tercapainya kepuasan pasien terhadap mutu makanan, dan adanya ketidaksesuaian berat porsi makanan lunak yang disajikan terhadap standar berat porsi makanan lunak rumah sakit diharapkan dapat memberikan masukan pada manajemen rumah sakit dalam mengevaluasi biaya makan pasien dan

\section{RUJUKAN}

1. Departemen Kesehatan RI. Buku Pedoman Pelayanan Gizi Rumah Sakit. Jakarta: Dirjen Pelayanan Medik, Direktorat Rumah Sakit Khusus Swasta; 2003.

2. Thompson $\mathrm{CH}$, Head MK, Rodman SM. Factor Influencing Accuracy in Estimating Plate Waste. J Am Diet Assoc 1987; 90: 381-90.

3. Departemen Kesehatan RI. Buku Pedoman Teknis Pelayanan Rawat Inap dan Rawat Jalan di Rumah Sakit. Jakarta: Dirjen Pelayanan Medik Direktorat Rumah Sakit Khusus Swasta; 1991.

4. Jeniati E. Hasil Studi tentang Pengelolaan Catering Rumah Sakit. Naskah Lengkap Seminar PERMAPKINHMRCE III; 24-26 Agustus 2004; Jakarta, Indonesia.

5. Instalasi Gizi RSUD Gunung Jati Kota Cirebon. Laporan Tahunan Instalasi Gizi RSUD Gunung Jati Kota Cirebon Tahun 2005. Cirebon: Instalasi Gizi RSUD Gunung Jati Kota Cirebon; 2005.

6. Mukrie N, Ginting AB, Ngadiarti I. Manajemen Pelayanan Gizi Institusi Dasar. Jakarta: Proyek Pengembangan Pendidikan Tenaga Gizi Pusat dan Akademi Gizi Departemen Kesehatan RI; 1990.

7. Almatsier S. Persepsi Pasien terhadap Makanan di Rumah Sakit. Jurnal Gizi Indonesia 1992;17:87-96.

8. Lemeshow S, Hosmer D, Klar J. 1990. Adequacy of Sample Size in Health Studies. (Terjemahan) Pramono D. Yogyakarta: UGM Press; 1997. mutu pelayanan penyelenggaraan makanan dengan sistem outsourcing. Indikator kepuasan pasien (perspektif pelanggan) juga perlu ditetapkan di instalasi gizi sebagai bahan evaluasi pencapaian kepuasan pasien terhadap mutu pelayanan makan. Perlu adanya penelitian lanjutan untuk menganalisis nilai gizi makanan yang hilang dari sisa makanan lunak pada penyelenggaraan makanan dengan sistem outsourcing, sehingga dapat menggambarkan mutu pelayanan makanan.

9. Law C, Gregoire MB. Quality Ratings in A Hospital Food Service Departement by Inpatient and Postdischarge Patient. J Am Diet Assoc 1998;98:1303-7.

10. Instalasi Gizi Dr. Sardjito. Laporan Instalasi Gizi Tahun 2001. Yogyakarta: RS Dr. Sardjito; Yogyakarta.

11. Setyowati. Kontribusi Makanan Luar Rumah Sakit terhadap Asupan Zat Gizi Pasien Rawat Inap serta FaktorFaktor yang Mempengaruhinya di RS Dr. Sardjito Yogyakarta [tesis]. Yogyakarta: Universitas Gadjah Mada; 2002.

12. Dwiyanti D, Hadi H, Susetyowati. Pengaruh Asupan Makanan terhadap Kejadian Malnutrisi di Rumah Sakit. Jurnal Gizi Klinik Indonesia 2004;1(1):1-7.

13. Moehji S. Pengaturan Makanan dan Diet Untuk Penyembuhan Penyakit. Jakarta: PT Gramedia Pustaka Utama; 1999.

14. Djamaluddin M, Prawirohartono EP, Paramastri I. Analisis Zat Gizi dan Biaya Sisa Makanan pada Pasien dengan Makanan Biasa di RS Dr. Sardjito Yogyakarta. Jurnal Gizi Klinik Indonesia 2004;1(3):108-12.

15. Suryana A. Pengembangan Tenaga Pengawas Makanan. Prosiding Kongres Nasional PERSAGI X dan KPIG; 21 23 November 1995; Bandung, Indonesia. 